\title{
PROGRESSIVE MANAGERIAL BONUSES IN A SPATIAL BERTRAND DUOPOLY
}

\author{
BARNA BAKÓ ${ }^{1}$ - ANDRÁS KÁLECZ-SIMON ${ }^{2}$ \\ ${ }^{1}$ Research fellow, MTA-BCE “Lendület” Strategic Interactions Research Group \\ Assistant lecturer, Corinus University of Budapest \\ Email: barna.bako@uni-corvinus.hu \\ ${ }^{2}$ Assistant lecturer, Corinus University of Budapest \\ Email: revelation.principle@gmail.com
}

The relationship of managerial bonuses and profit maximization is interesting both from an economic and a managerial viewpoint. Our contribution to this literature is showing that progressive managerial bonuses can increase profits in a spatial Bertrand competition, and furthermore they can help collusion.

Keywords: strategic delegation, managerial incentives

JEL codes: D21, L13

\section{INTRODUCTION}

The relationship of managerial bonuses and profit maximization is interesting both from an economic and a managerial points of view. On one hand, we see that using an adequate compensation scheme, the owners can commit themself to a market strategy which can increase their profits, compared to results achieved through direct profit maximization. Secondly, it can serve as a guideline for the comparison of different compensation plans.

The seminal articles in this area are Vickers (1985), Fershtman and Judd (1987), Sklivas (1987). The Cournot case was discussed in Jansen et al. (2009), while the Bertrand case was dealt with in Jansen et al. (2007). We are investigating the issue of managerial incentives in a spatial Bertrand model, in the vein of Hotelling (1929). Our contribution is showing that progressive managerial bonuses can increase profits in a spatial Bertrand competition, and furthermore they can help collusion.

\section{THE MODEL}

We investigate a spatial Bertrand duopoly. The two firms are located at points 0 and 1 respectively, and the line segment between the two locations is uniformly populated by consumers. Both firms have constant marginal costs, which is normalized to 0. A consumer located at point $x \in[0,1]$ buying the product of firm $i(i=1,2)$ has to pay the price set by firm $i$ plus the transportation cost $t$ per unit distance: $p_{i}+t\left|\left(l_{i}-1\right)-x\right|$, where $1_{i} \in\{0,1\}$ is the location of firm i. Each consumer buys at most one good. We further assume that the valuations of the customers are sufficiently high, so that in equilibrium each consumer is buying one good. The firms' decisions are made by their respective managers, who want to 
maximize their own salary. ${ }^{1}$ Their salaries in turn depend on the performance of the firm and the contract between the manager and the owner of the firm. We consider three types of contracts:

- Profit maximization. The manager's salary depends solely on the profit of the firm, thus they maximize the firm's profit function: $\pi_{\mathrm{i}}$.

- Flat bonus. The manager's salary depends not only on the profit of the firm, but the unit profit margin as well, thus they maximize the following function: $\pi_{\mathrm{i}}+\lambda_{\mathrm{i}} \mathrm{p}_{\mathrm{i}}$, where $p_{i}$ is the normalized price, i.e. the unit profit margin and $\lambda_{i}$ is a coefficient set by the owner. It can be shown that in our model this is equivalent to other types of bonuses studied in the literature: a quantity bonus or a market share bonus. See the appendix for details.

- Progressive bonus. The manager's salary depends not only on the profit of the firm, but also receives a progressive reward based on the profit margin, thus they maximize the following function: ${ }^{2} \pi_{\mathrm{i}}+\lambda_{\mathrm{i}} \mathrm{p}_{\mathrm{i}}{ }^{2}$.

We omitted the discussion of relative profit maximization, since it is easy to see that in this context the optimal contract offered by the owner would reward higher profits of the competitor, thus it is unfeasible.

For later comparisons, we reiterate a well-known result: If both firms are maximizing profits (i.e. if both managers are given profit maximizing contracts), then the profit maximizing price for firm $i$ is $p_{i}=\left(p_{-i}+t\right) / 2$, where $p_{-i}$ is the price set by the other firm, then both firms charge $t$ and the profits of both firms are $t / 2$.

\section{RESULTS}

If the manager of firm $\mathrm{i}$ is given a flat bonus contract, the following price maximizes their salary (conditional on the bonus coefficient and the price charged by the other firm): $p_{i}=\left[p_{-i}+\right.$ $\left.\mathrm{t}\left(1+2 \lambda_{\mathrm{i}}\right)\right] / 2$, where $-\mathrm{i} \neq \mathrm{i}$. Using this, we can state the following propositions:

Proposition 1. If the manager of firm $\mathrm{i}$ is given a flat bonus contract and the manager of firm $\mathrm{i}$ is given a profit maximizing contract then the respective prices and profits are:

$$
\begin{array}{ll}
\mathrm{p}_{\mathrm{i}}=(3 \mathrm{t}) / 2, & \mathrm{p}_{-\mathrm{i}}=(5 \mathrm{t}) / 4 \\
\pi_{\mathrm{i}}=(9 \mathrm{t}) / 16, & \pi_{-\mathrm{i}}=(25 \mathrm{t}) / 32
\end{array}
$$

Proposition 2. If the managers of both firms are given a flat bonus contract then the respective prices and profits are:

$$
\begin{array}{ll}
\mathrm{p}_{\mathrm{i}}=2 \mathrm{t}, & \mathrm{p}_{-\mathrm{i}}=2 \mathrm{t} \\
\pi_{\mathrm{i}}=\mathrm{t}, & \pi_{-\mathrm{i}}=\mathrm{t}
\end{array}
$$

If the manager of firm $i$ is given a progressive bonus contract, the following price maximizes their salary (conditional on the bonus coefficient and the price charged by the other firm): $p_{i}=$ $\left(\mathrm{p}_{-\mathrm{i}}+\mathrm{t}\right) /\left[2\left(1-\lambda_{\mathrm{i}} \mathrm{t}\right)\right]$. That leads us to three further propositions:

\footnotetext{
1 This salary might consist of a fixed part, a commission proportional to the profit and some kind of bonus.

2 To capture the progressiveness of the bonus schedule, we used a strictly convex function of the profit margin.
} 
Proposition 3. If the manager of firm i is given a progressive bonus contract and the manager of firm -i is given a profit maximizing contract then the respective prices and profits are:

$$
\begin{array}{ll}
\mathrm{p}_{\mathrm{i}}=(3 \mathrm{t}) / 2, & \mathrm{p}_{-\mathrm{i}}=(5 \mathrm{t}) / 4 \\
\pi_{\mathrm{i}}=(9 \mathrm{t}) / 16, & \pi_{-\mathrm{i}}=(25 \mathrm{t}) / 32
\end{array}
$$

Proposition 4. If the manager of firm $\mathrm{i}$ is given a progressive bonus contract and the manager of firm - $\mathrm{i}$ is given a flat bonus contract then the respective prices and profits are:

$$
\begin{array}{ll}
\mathrm{p}_{\mathrm{i}}=(7 \mathrm{t}) / 3, & \mathrm{p}_{-\mathrm{i}}=(5 \mathrm{t}) / 2 \\
\pi_{\mathrm{i}}=(49 \mathrm{t}) / 36, & \pi_{-\mathrm{i}}=(25 \mathrm{t}) / 24
\end{array}
$$

Proposition 5. If the managers of both firms are given a progressive bonus contract then the respective prices and profits are:

$$
\begin{array}{ll}
\mathrm{p}_{\mathrm{i}}=\mathrm{p}_{\text {coll }}, & \mathrm{p}_{-\mathrm{i}}=\mathrm{p}_{\text {coll }} \\
\pi_{\mathrm{i}}=\pi_{\text {coll }}, & \pi_{-\mathrm{i}}=\pi_{\text {coll }}
\end{array}
$$

In this case, no upper boundary on consumer valuations would mean no upper boundary on optimal prices; therefore with a more realistic assumption of bounded valuations both firms would charge the collusive price and earn the collusive profits.

\section{DISCUSSION}

Though it is quite unlikely that real-life contracts would incorporate the square of some profitability measure, it can be practically emulated by offering contacts with profitability targets and assign a progressively increasing reward. We have seen that considering the described set of strategies it is a weakly dominant strategy, thus in some cases it can increase the firm's profits. Furthermore if the owners of both firms offer this type of contract, it can facilitate collusion in the industry.

\section{APPENDIX}

\section{The equivalence of profitability, quantity and market share bonuses}

The manager of firm $i$, if offered a quantity bonus, maximizes $\pi_{i}+\lambda_{i} q_{i}$, where $q_{i}$ is the number of units sold. It is trivial that $\mathrm{q}_{\mathrm{i}}$ is also the market share of firm $\mathrm{i}$ in this setup, so we only have to show that this compensation system leads to the same result as the bonus system proposed in the article. The price that maximizes the payoff to the manager under the quantity bonus system is: $p_{i}=\left(-\lambda_{i}+p_{-i}+t\right) / 2$.

Now assume that choosing $\lambda_{\mathrm{i}}=\alpha$ maximizes the payoff to the owner. If the manager would have had a profitability bonus, so the manager would choose price $\mathrm{p}_{\mathrm{i}}=\left[\mathrm{p}_{-\mathrm{i}}+\mathrm{t}\left(1+2 \lambda_{\mathrm{i}}\right)\right] / 2$. In the latter case, choosing $\lambda_{i}=-\alpha /(2 t)$ produces the same outcome as that in the case of the quantity bonus.

Assume that in the profitability bonus case, choosing $\lambda_{\mathrm{i}}=\beta$ maximizes the payoff to the owner. An owner, having offered the quantity bonus contract, could replicate the same outcome by choosing $\lambda_{i}=-\beta /(2 t)$. 
We can see that the optimal lambdas have an opposite sign, thus formulating the contract as a quantity or market share bonus may not be feasible.

\section{The managerial decisions}

The flat bonus case

The manager of firm i maximizes

$$
U_{i}\left(p_{i}\right)=\left[\left(-p_{i}+p_{-i}+t\right) /(2 t)\right] p_{i}+\lambda_{i} p_{i}
$$

so the first-order condition is

$$
\partial \mathrm{U}_{\mathrm{i}}\left(\mathrm{p}_{\mathrm{i}}\right) / \partial \mathrm{p}_{\mathrm{i}}=\lambda_{\mathrm{i}}-\left(\mathrm{p}_{\mathrm{i}}\right) /(2 \mathrm{t})+\left(-\mathrm{p}_{\mathrm{i}}+\mathrm{p}_{-\mathrm{i}}+\mathrm{t}\right) /(2 \mathrm{t})=0
$$

The progressive bonus case

The manager of firm i maximizes

$$
\mathrm{U}_{\mathrm{i}}\left(\mathrm{p}_{\mathrm{i}}\right)=\left[\left(-\mathrm{p}_{\mathrm{i}}+\mathrm{p}_{-\mathrm{i}}+\mathrm{t}\right) /(2 \mathrm{t})\right] \mathrm{p}_{\mathrm{i}}+\lambda_{\mathrm{i}} \mathrm{p}_{\mathrm{i}}^{2}
$$

so the first-order condition is

$$
\partial U_{i}\left(p_{i}\right) / \partial p_{i}=2 \lambda_{i} p_{i}-\left(p_{i}\right) /(2 t)+\left(-p_{i}+p_{-i}+t\right) /(2 t)=0
$$

\section{The optimal incentives}

Flat bonus and profit maximization

Assume that the manager of firm $i$ is working under a flat bonus contract, while the manager of firm -i maximizes profits. In that case the managers choose the following prices:

$$
\mathrm{p}_{\mathrm{i}}=\left(3+4 \lambda_{\mathrm{i}}\right) \mathrm{t} / 3, \quad \mathrm{p}_{-\mathrm{i}}=\left(3+2 \lambda_{\mathrm{i}}\right) \mathrm{t} / 3
$$

Thus the owner of firm i maximizes their profit according to the first-order condition:

$$
\partial \pi_{\mathrm{i}} / \partial \mathrm{p}_{\mathrm{i}}=\left(3-8 \lambda_{\mathrm{i}}\right) \mathrm{t} / 9=0 \text {. }
$$

hence

$$
\lambda_{\mathrm{i}}=3 / 8
$$

Both owners offer flat bonus

If both owners offer flat bonus contracts to the managers, then the managers choose the following prices:

$$
\mathrm{p}_{\mathrm{i}}=\left(3+4 \lambda_{\mathrm{i}}+2 \lambda_{-\mathrm{i}}\right) \mathrm{t} / 3, \quad \mathrm{p}_{-\mathrm{i}}=\left(3+2 \lambda_{\mathrm{i}}+4 \lambda_{-\mathrm{i}}\right) \mathrm{t} / 3
$$

Thus the owner of firm i maximizes their profit according to the first-order condition: 


$$
\partial \pi_{\mathrm{i}} / \partial \mathrm{p}_{\mathrm{i}}=\left(3-8 \lambda_{\mathrm{i}}+2 \lambda_{-\mathrm{i}}\right) \mathrm{t} / 9=0
$$

hence

$$
\lambda_{\mathrm{i}}=\left(3+2 \lambda_{-\mathrm{i}}\right) / 8
$$

Using a similar condition derived for firm -i, the optimal coefficients can be calculated:

$$
\lambda_{\mathrm{i}}=\lambda_{-\mathrm{i}}=1 / 2 \text {. }
$$

Progressive bonus and profit maximization

Assume that the manager of firm $i$ is working under a progressive bonus contract, while the manager of firm -i maximizes profits. In that case the managers choose the following prices:

$$
\mathrm{p}_{\mathrm{i}}=3 \mathrm{t} /\left(3-8 \lambda_{\mathrm{i}} \mathrm{t}\right), \quad \mathrm{p}_{-\mathrm{i}}=\left(3 \mathrm{t}-4 \lambda_{\mathrm{i}} \mathrm{t}^{2}\right) /\left(3-8 \lambda_{\mathrm{i}} \mathrm{t}\right)
$$

Thus the owner of firm i maximizes their profit according to the first-order condition:

$$
\partial \pi_{\mathrm{i}} / \partial \mathrm{p}_{\mathrm{i}}=18 \mathrm{t}^{2}\left(1-8 \lambda_{\mathrm{i}} \mathrm{t}\right) /\left(3-8 \lambda_{\mathrm{i}} \mathrm{t}\right)^{3}=0
$$

hence

$$
\lambda_{\mathrm{i}}=1 /(8 \mathrm{t}) .
$$

Progressive bonus and flat bonus

Assume that the manager of firm $i$ is working under a progressive bonus contract, while the manager of firm $-i$ receives a flat bonus. In that case the managers choose the following prices:

$$
\mathrm{p}_{\mathrm{i}}=\left(3 \mathrm{t}+2 \lambda_{-\mathrm{i}} \mathrm{t}\right) /\left(3-8 \lambda_{\mathrm{i}} \mathrm{t}\right), \quad \mathrm{p}_{-\mathrm{i}}=\left(3 \mathrm{t}+4 \lambda_{-\mathrm{i}}-4 \lambda_{\mathrm{i}} \mathrm{t}^{2}-8 \lambda_{\mathrm{i}} \lambda_{-\mathrm{i}} \mathrm{t}^{2}\right) /\left(3-8 \lambda_{\mathrm{i}} \mathrm{t}\right)
$$

Thus the owner of firm i maximizes their profit according to the first-order condition:

$$
\partial \pi_{\mathrm{i}} / \partial \mathrm{p}_{\mathrm{i}}=2\left(3+2 \lambda_{-\mathrm{i}}\right)^{2} \mathrm{t}^{2}\left(1-8 \lambda_{\mathrm{i}} \mathrm{t}\right) /\left(3-8 \lambda_{\mathrm{i}} \mathrm{t}\right)^{3}=0
$$

hence

$$
\lambda_{\mathrm{i}}=1 /(8 \mathrm{t}) .
$$

The owner of firm -i maximizes their profit according to the first-order condition:

$$
\partial \pi_{-i} / \partial \mathrm{p}_{-\mathrm{i}}=\mathrm{t}\left\{3-4 \lambda_{\mathrm{i}} \mathrm{t}-8 \lambda_{-\mathrm{i}}\left[1+2 \lambda_{\mathrm{i}} \mathrm{t}\left(-3+4 \lambda_{\mathrm{i}} \mathrm{t}\right)\right]\right\} /\left(3-8 \lambda_{\mathrm{i}} \mathrm{t}\right)^{2}=0
$$

hence

$$
\lambda_{-i}=\left(3-4 \lambda_{\mathrm{i}} \mathrm{t}\right) /\left[8\left(1-6 \lambda_{\mathrm{i}} \mathrm{t}+8 \lambda_{\mathrm{i}}^{2} \mathrm{t}^{2}\right)\right]
$$

which - after the substitution of the previously calculated value for $\lambda_{i}-$ gives: 


$$
\lambda_{-\mathrm{i}}=5 / 6
$$

Both owners offer progressive bonus

If both owners offer progressive bonus contracts to the managers, then - still assuming unbounded consumer valuations - the managers choose the following prices:

$$
\begin{aligned}
& \mathrm{p}_{\mathrm{i}}=\left(3 \mathrm{t}-4 \lambda_{-\mathrm{i}} \mathrm{t}^{2}\right) /\left(3-8 \lambda_{\mathrm{i}} \mathrm{t}-8 \lambda_{-\mathrm{i}} \mathrm{t}+16 \lambda_{\mathrm{i}} \lambda_{-\mathrm{i}} \mathrm{t}^{2}\right), \\
& \mathrm{p}_{-\mathrm{i}}=\left(3 \mathrm{t}-4 \lambda_{\mathrm{i}} \mathrm{t}^{2}\right) /\left(3-8 \lambda_{\mathrm{i}} \mathrm{t}-8 \lambda_{-\mathrm{i}} \mathrm{t}+16 \lambda_{\mathrm{i}} \lambda_{-\mathrm{i}} \mathrm{t}^{2}\right)
\end{aligned}
$$

Thus the owner of firm i maximizes their profit according to the first-order condition:

$$
\partial \pi_{-i} / \partial p_{-i}=2 t^{2}\left(3-4 \lambda_{-i} t\right)^{2}\left[1+8 \lambda_{i} t\left(2 \lambda_{-i} t-1\right)\right]^{3} /\left(3-8 \lambda_{i} t-8 \lambda_{-i} t+16 \lambda_{i} \lambda_{-i} t^{2}\right)=0
$$

hence

$$
\lambda_{\mathrm{i}}=1 /\left[8 \mathrm{t}\left(1-2 \lambda_{-\mathrm{i}} \mathrm{t}\right)\right]
$$

Using a similar condition derived for firm $\mathrm{j}$, the optimal coefficients can be calculated:

$$
\lambda_{\mathrm{i}}=\lambda_{-\mathrm{i}}=1 / 4 \text {. }
$$

\section{REFERENCES}

Fershtman, C. - Judd, K. L (1987): Equilibrium incentives in oligopoly. American Economic Review 77(5): 927-940.

Hotelling, H. (1929): Stability in competition. Economic Journal 39(153): 41-57.

Jansen, T. - van Lier, A. - van Witteloostuijn, A. (2007): A note on strategic delegation: The market share case. International Journal of Industrial Organization 25(3): 531-539.

Jansen, T. - van Lier, A. - van Witteloostuijn, A. (2009): On the impact of managerial bonus systems on firm profit and market competition: the cases of pure profit, sales, market share and relative profits compared. Managerial and Decision Economics 30(3): 141153.

Sklivas, S. D. (1987): The strategic choice of managerial incentives. RAND Journal of Economics 18(3): 452-458.

Vickers, J. (1985): Delegation and the theory of the firm. Economic Journal 95(380a): 138147. 